\author{
Julio Hans C. Jensen
}

\title{
Antropomorfismens reversibilitet
}

\section{Perception og tekstualitet i lyrikken}

Et en un sens, comme dit Valéry, le langage est tout, puisqu'il n'est la voix de personne, qu'il est la voix même des choses, des ondes et des bois.

- Merleau-Ponty

Betoningen af litteraturens rent tekstuelle aspekt i strukturalistisk og poststrukturalistisk litteraturteori medfører som bekendt en prekær forståelse af forholdet mellem litterære tekster og ekstralingvistiske instanser. Ud fra disse teoretiske perspektiver er litteraturen betragtet som en autonom sfære regeret af lingvistiske strukturer og retoriske transformationer snarere end af noget forhold mellem de litterære tekster og en given historisk og eksistentiel virkelighed. I kontrast hertil indtager tænkere som Paul Ricœur, Ernst Cassirer eller Maurice Merleau-Ponty en position der giver sproget en medierende rolle mellem subjekt og verden. Disse filosoffer betragter sproget som grundlagt på en erfaring af subjektets kropslige væren i verden, samtidig med at det kaster lys på denne erfaring. Sproget gives således en dobbelt position: på den ene side udspringer det af en biologisk givethed som det henviser til, og på den anden side artikulerer det og skaber således også vores erfaring af verden. I forlængelse af denne anskuelse er det hensigten med nærværende artikel at foreslå hvorledes man i den litterære analyse kan betragte antropomorfismen som en paradigmatisk trope for denne sprogopfattelse. I overensstemmelse hermed vil en antropomorfisme være en henvisning til en primær subjektiv erfaring af verden samtidig med, at denne trope også er en formning af vores forståelse af verden.

I Paul de Mans berømte læsning af Baudelaires sonet »Correspondances«, "Anthropomorphism and Trope in the Lyric«, defineres lyrikken som en genre udspændt mellem kategorierne trope og antropomorfisme. Ifølge de Man repræsenterer tropen »de tropologiske transformationers uendelige kæde, «1 
mens antropomorfismen skal betragtes som »en identifikation på substansniveau« ( $R R$, p.241), som fikserer tropernes uendelige forvandlinger. Antropomorfisme og trope repræsenterer efter de Mans opfattelse to poler for sprogets udfoldelse: enten følger sproget sin selvtransformerende dynamik, eller det udkrystalliserer i »fortolkningssystemer såsom antropomorfismer« $(R R$, p. 242). Troper som metaforen eller metonymien betragtes således af de Man som udelukkende strukturelt bestemt, åbne for ubegrænsede transformationer. I modsætning hertil indebærer en antropomorfisme nødvendigvis en semantisk determination. Troperne effektuerer tekstualitetens uafgørlighed, mens en antropomorfisme sætter en mening, hvilket hos de Man er det samme som at fortolke. Årsagen til at antropomorfismen skulle være en semantisk determination bliver ikke angivet af de Man, men man kunne antage, at det skyldes dens henvisning til en menneskelig krop og til en menneskelig væren. Imidlertid findes en sådan referentiel funktion ikke i de Mans sprogopfattelse. Som en eksemplifikation af de to poler i sprogudfoldelsen finder de Man, at »Correspondances« repræsenterer den tropologiske transport, mens et andet digt fra Les fleurs du mal, „Obsession«, fremviser »tropens forvandling til antropomorfisme« $(R R, \mathrm{p} .261)$. Argumentet er at tropen altid er til stede når antropomorfiseringen indtræder: „Når vi møder en tekst som »Obsession« (...) er der altid en infra-tekst, et hypogram som »Correspondances« nedenunder. At formulere dette forhold (...) frembringer med det samme en hermeneutisk, fejlagtig lyrisk læsning af det uforståelige« (RR, p.262). Fordi tropologien altid er på spil i selv de mest monolitisk entydige tekster, er den enhver teksts infratekst. Endvidere er tropologien »lyrikkens hele mulighedsbetingelse« $(R R, p .262)$, idet den kan overtages af en stemme, som vil være ensbetydende med en antropomorfisering. Denne overtagelse vil imidlertid altid være voldelig (»violent«, $R R$, p.262), eftersom den fastfryser tropernes transformationer i fortolkningssystemer.

Konflikten mellem trope og antropomorfisering er for de Man et uundgåeligt vilkår, hvor primatet er at finde i det inhumane eller ikke-antropomorfe aspekt i sproget. Det underliggende postulat er - i uudtalt samtykke både med Jakobsons definition af den poetiske funktion i sproget og med strukturalismens heuristiske afskæring af sprogsystemets referentielle funktion - at den poetiske sprogbrug ikke holder nogen forbindelse med den perceptuelle verden. Lyrikken er resultatet af et transformativt tegnsystem udfoldet i en autonom sfære, hvor kun interne relationer forekommer. Heraf uddrager de Man den konsekvens, at poesi er et produkt af en upersonlig og immanent lingvistisk »kraft« eller »dynamik« snarere end frembragt af et givent historisk og eksistentielt subjekt. Intentionen er at hævde, at lyrikken - repræsentationen af et subjekts stemme - har sin oprindelse i de non-humane tropologi- 
ske transformationer. Uoverensstemmelsen mellem en fænomenologisk væren i verden og det poetiske udtryk synes således klar, idet sprogets og retorikkens immanens medfører den lyriske subjektivitets grundlæggende retoricitet. Det lyriske subjekt betragtes med andre ord som en fiktion, der hviler på retoriske transformationer snarere end på erfaringer indsamlet i en perceptuel verden.

Denne sprogopfattelse - herunder dens forståelse af poesien - står i skarp kontrast til en filosofisk fænomenologisk og hermeneutisk tradition. Overfor de Mans metafordefinition som en rent strukturel transformation forelægger Paul Ricœur et metaforbegreb, som indeholder en referentialitet til erfaringens og perceptionens verden. Af denne grund kan en metafor lykkes eller mislykkes: „Den kan mislykkes som i forcerede metaforer fordi de er inkonsistente eller vilkårlige eller på grund af det modsatte, i metaforer som er almindeligheder; og en metafor kan lykkes i de tilfælde den frembringer opdagelsens overraskelse. $\ll^{2}$ Eftersom en metafor indeholder en henvisning til eksisterende entiteter i verden er det ikke den blotte lingvistiske struktur der afgør hvorvidt der er tale om en metafor, men afsløringen af en affinitet mellem de sammenlignede elementer. Dette betyder, at metaforen er defineret ved sin semantik og ikke ved sin syntagmatiske form. ${ }^{3}$ En metafor har en »billeddannende funktion « ${ }^{4}$ eller, med andre ord, et i Peirces forstand ikonisk aspekt, som får os til at se en given ting som en anden. Metaforens billeddannende funktion er ikke en blot deiktisk henvisning til et givent fænomen, men en refiguration af det. Ved at se et fænomen som noget andet åbenbares et nyt aspekt ved verden. Metaforen besidder altså også en kognitiv funktion i sin referentialitet. Denne referentialitet er imidlertid ikke af samme art som hverdagssprogets henvisninger, hvorfor Ricœur kalder den en andengrads referentialitet. At se en given ting som en anden indebærer umiddelbart en logisk absurditet (Julie er unægteligt ikke solen i Shakespeares »Juliet is the sun«), men netop derfor kalder denne operation på en fortolkning hos modtageren. Heri består det hermeneutiske aspekt ved Ricœurs metaforteori, som altså forener referentialitet til verden og sproglig formning af vores erfaring af verden. Metaforen som et sprogligt fænomen udspringer således af vores omgang med verden, men samtidig bidrager metaforen til vores erkendelse af verden ved at udvide vores forståelse af den.

Inden Ricœurs indsigter om refigurationen af verden gennem metaforen fremstilles videre, vil en henvisning til Ernst Cassirers værk Philosophie der symbolischen Formen forklare, hvorledes antropomorfismer specifikt indeholder en referentialitet til verden og vores beboelse af den. Cassirers neokantianske filosofi udviser i mange henseender fælles træk med Ricœurs hermeneutiske fænomenologi, i og med den også tilskriver kulturen generelt og 
sproget specielt en afgørende rolle for vores erkendelse af verden. Hos Cassirer kaldes de diskursive eller kulturelle formationer »symbolske former «. Den menneskelige kultur har gennem historien udviklet en række symbolske former (myter, kunstarter, videnskab), som hver skænker sin egen artikulation af verden. ${ }^{5}$ De styrer vores erfaring og viden og er historisk udviklet gennem kommunikation og fortolkning. Erfaringen af verden udvikles således i kraft af den specifikke symbolske form (det specifikke kulturelle domæne), som i en given situation artikulerer forholdet mellem subjekt og objekt, rum og tid, selv og verden etc. ${ }^{6}$

Cassirer definerer den meningsgivende funktion i de symbolske former som baseret på to grundlæggende egenskaber i vores omgang med verden, nemlig udtryksfunktion (Ausdrucksfunktion) og udtryksperception (Ausdruckswahrnehmung). Forud for erfaringen af en verden af objekter og forud for vores selvbevidsthed som subjekter ligger en umiddelbar og spontan følelse af intersubjektiv kommunikation som styrer vores erfaring: 'du' går forud for 'det'. ${ }^{7}$ Den mest grundlæggende perception er registreringen af et kropsligt udtryk hos et andet subjekt: et smil, en panderynken, et kærtegn, etc. (PSF III, p.102). Denne udtryksperception er funderet i den levende krop idet denne er den transcendentale grund for enhver symbolsk form:

„Forholdet mellem krop og sjæl fremsætter det første forbillede og mønsterbillede for en rent symbolsk relation som ikke lader sig omtænke, hverken i en tingsrelation eller i en kausalforbindelse. Her er der oprindeligt ikke et inde og ude, et før eller efter, et som virker og et som er bevirket. Her regerer en sammenknytning som ikke først skal sammenføjes af adskilte elementer men som er et primært meningsfyldt hele som fortolker sig selv«(PSF III, p.117).

Udtryksperceptionen ligger således forud for de kantianske anskuelses- og forstandsformer som rum, tid og årsag-virkningsfølge. En sansende krop besidder en prækulturel eller 'naturlig' symbolisme, der skal forstås som den arke-symbolske form i hvilken al viden og erfaring er rodfæstet. Et af Cassirers eksempler på, at den kropslige væren i verden er grundlag for og rækker ind i enhver form for forståelse er samtalen, idet en sætnings melodiske og rytmiske frasering er en uomgængelig forudsætning for dens tilegnelse hos modtageren (tydeligst i formuleringen af et spørgsmål eller et udråb). Sproget kan kun forstås som en forening af sanserne og intellektet eftersom det kun eksisterer — med et udtryk som foregriber Merleau-Pontys filosofisom en »Verkörperung des Logos« (PSF III, p.129). 
Denne kroppens ursymbolske funktion ligger således til grund for den første egentlige symbolske formation, den mytiske diskurs. Mytens verden er gennemtrængt af følelser, handlinger, fjendtligt- og venligtsindede kræfter etc. Cassirer forklarer mytens repræsentation af verden ved, at den bliver anskuet som om den havde et menneskeligt ansigt: »Verden har, som helhed og i enkeltdelene, stadig et særegent 'ansigt' "(PSF III, p. 80). Udtryksperceptionen åbner verden i en symbolsk form som giver mulighed for at tale om den og fortolke den. Erfaringen af virkeligheden er altså ikke at modtage neutrale sanseindtryk, men er givet ved den grundlæggende udtryksperception uden hvilken verden ville forblive meningsløs: „Uden den kendsgerning at en udtryksmening åbenbares i bestemte perceptionsoplevelser ville tilværelsen forblive stum for os«(PSF III, p. 86). Det er således tydeligt hvordan Cassirers teori om de symbolske former repræsenterer en filosofisk position, som giver en forklaring på forekomsten af antropomorfismer i lyrikken. At se den ydre verden som et menneskeligt ansigt er en tilgang til verden, som tilhører en primær symbolsk form i kulturhistorien, nemlig myten. Antropomorfiseringer i lyrikken er således, snarere end en blot retorisk transformation, et vidnesbyrd om den mest grundlæggende perceptionserfaring, d.v.s. den tilgang til verden, som åbner den for os i en symbolsk relation.

Et fordelagtigt udgangspunkt hvorfra man kan udfolde implikationerne af brugen af antropomorfismer i lyrikken er at finde i den romantiske og postromantiske periode. Selvom antropomorfismer kan observeres i al poesi til alle tider, bør de i romantisk og postromantisk lyrik ses som en artikulation og understregning af erfaringen af at høre til naturverdenen - hvilket jo er et hovedtema i det romantiske projekt. Baudelaires »Correspondances« udtrykker således temaet om slægtskabet med naturen:

Naturen er et Tempel, hvor levende Søjler står

hviskende på dunkle, ugranskelige Love.

Mennesket må vandre gennem Symbolers Skove, som med fortrolige Blikke følger ham, hvor han går. ${ }^{8}$

Digtersubjektet er i dette paradigme formidleren mellem indre og ydre natur samt mellem natur og kultur, og dette er baggrunden for den figurative krydsning af natur- og kulturelementer man kan iagttage i ovenstående citat. Det viser sig tilsvarende i poesien fra denne periode, at antropomorfiseringen af naturen er reversibel. Det lyriske subjekt som betragter naturen ser ikke kun denne med antropomorfe træk, men repræsenterer tillige subjektiviteten - herunder de subjektive stemninger - som naturelementer. Denne reversibilitet eller korrespondance mellem subjekt- og natursfære har Michael Riffa- 
terre kaldt prosopopoeens kiastiske struktur: »enten vil subjektet overtage objektet eller det vil blive gennemtrængt af objektet. « ${ }^{9}$ Med henvisning til de Man bemærker Riffaterre, at det besjælede objekt vil skue tilbage på subjektet, idet »de Man sætter en følge af prosopopeen: påkaldelsen indbyder til et svar fra den påkaldte; blikket som fornemmer besjælingen kalder på et blik tilbage fra det besjælede objekt på det subjekt som dagdrømmer en narcissistisk selvspejling i tingene«.$^{10}$ I konsekvens heraf hedder antropomorfismens revers naturalisering ("naturalization«, $R R$, p. 255). Implikationerne af denne reversibilitet - herunder hvorvidt den udelukkende repræsenterer en narcissistisk besjæling af naturen - kan bedst fremdrages ved en konkret analyse, hvilket skal udføres i det følgende ud fra en tekst af den spanske digter Juan Ramón Jiménez. ${ }^{11}$

I Jiménez' tidlige poesi er digtenes scenarier næsten udelukkende ydre naturrum: en dal, haver, bjergene bag hvilke solen går ned, etc. I disse idealiserede naturscenerier etablerer det lyriske subjekt en korrespondance mellem sin indre emotionelle tilstand og landskabet. Læseren mødes således med en kiastisk gennemtrængning af natur og følelser, der artikuleres i den netop nævnte reversibilitet mellem antropomorfisering af naturen og naturalisering af det lyriske subjekt. I det symbolistiske digt »Primavera y sentimiento《 (»Forår og følelse «), fra samlingen Rimas (Rim, 1902), betragter det lyriske subjekt solnedgangen fra en have med fontæner, blomster hvis dufte stiger mod himlen og stier, der fortaber sig i skumringen. Det lyriske subjekt udtrykker ønsket om at blive opløst i naturtotaliteten både ved digtets start og ved dets afslutning (»sjælen / ønsker at fortabe sig i briserne«, v. 2-3 og »Hvem der blot kunne opløses / i denne så vage farve / som oversvømmer rummet med / rene, duftende og hvide bølger« v.71-74). I første strofe, efter at det lyriske subjekt har udtrykt ønsket om at blive opløst i naturen, optræder havens blomster med en egen vilje og stjernerne siges at have en pande: »de essenser / som blomsterne hæver / for at parfumere / de tidlige stjerners pander« (v. 7-10). ${ }^{12}$ Læseren konfronteres således med antropomorfiseringen af et naturelement umiddelbart efter det lyriske subjekts eksplicitte ønske om at opløses i naturen. Denne sammenstilling er logisk betragtet paradoksal eftersom opløsningen i naturen skulle indebære udslettelsen af ethvert antropomorft træk, mens personifikationen af et naturelement er en modsatrettet operation, humaniseringen af naturen. Men dette er netop reversibilitetens kendetegn: en korrespondance mellem subjektivitet og natur der svarer til en - som det vil blive vist med reference til Ricœur - præobjektiv tilgang til væren, hvor indre og ydre, subjektivitet og natur ikke er kategorialt adskilt. 
Den figurative ombytning af indre og ydre kan iagttages ved hjælp af blomstermotivet, for mens havens blomster sendte deres dufte til himlen i første strofe, og jeg'ets indre blomst udfører den samme handling (»min sjæls roses / melankolske blomsterblade skælver / og deres søde duft / (minder, kærlighed, nostalgi) / stiger mod det rolige blå«, v. 11-15), vendes denne bevægelse om i tredie strofe. Her stiger en duft af 'nye blomster' ned fra himlen: »fra himlens kildevæld / (kildevæld af frisk vellugt), / bringer briserne fra drømmens / riger en duft af nye blomster / til jorden« (v. 28-32), hvor »himlens kildevæld« således bliver identificeret med »drømmens riger«.

Det kiastiske forhold mellem det lyriske subjekts indre rum og naturrummet kan også observeres på et stiltræk som i høj grad karakteriserer symbolisme og impressionisme, nemlig at sanserfaringen ikke udtrykkes via et aktivt, eksplicit jeg, men ved kun at benævne sanseerfaringen selv. I løbet af de første tre strofer udtrykker det lyriske subjekt ikke sine perceptioner i første person. Enten er de udtrykt som erfaret i tredie person - sjælen er subjektet for erfaringen - eller de bliver repræsenteret uden at jeg'et ekspliciteres: „fra himlens kildevæld / (kildevæld af frisk vellugt), / bringer briserne fra drømmens / riger en duft af nye blomster / til jorden« (v. 30-32), »i den grønlige himmels / gennemsigtige bølge / driver sukkes mystik« (v. 3739). Denne impersonalitet i perceptionen bliver yderligere understreget ved brugen af refleksive og intransitive verber (fortabe sig, beruse sig, skælve, hæve sig, opløse sig, strække sig, bevæge sig, drive), ${ }^{13}$ som på spansk sætter fokus på den verbale akt i sig selv i stedet for på dens subjekt eller objekt. ${ }^{14}$ Herved bliver subjektet til et passivt, næsten fraværende objekt for perceptionen. Ligeledes fremhæver brugen af synæstesier perceptionen selv snarere end dens subjekt, f.eks. i digtets første linier, hvor farve og duft sammenstilles i subjektets ønske om at »beruse sig med den vage / uudsigelige farve som himlen / lader vælde ned ad rummet / og smelter sammen med de essenser / som blomsterne hæver« (v. 4-8). Herved bliver en overindividuel eller upersonlig fænomenologisk høren til verden repræsenteret, hvilket er Correspondance-sonettens egentligt subjektopløsende indebyrd snarere end, som de Man hævder, udfoldelsen af den non-humane tropologiske kæde.

Det er imidlertid muligt at iagttage to tematiske tekstdele $\mathrm{i}$ »Primavera y sentimiento«. Hvis digtets tre første strofer ligger i forlængelse af forholdet mellem subjekt og verden udfoldet $\mathrm{i}$ »Correspondances, « så negeres denne anskuelse i de to sidste strofer. I fjerde strofes første linier erfarer det lyriske subjekt en adskillelse fra den kosmiske orden, idet der udtrykkes tvivl om, hvorvidt en sådan orden overhovedet findes: »Det ser ud som om stjernerne / medfølende taler til mig / men da de er så fjerne / forstår jeg ikke deres tale« (v. 43-46). De efterfølgende vers (46-51) fortsætter negationen af kom- 
munikationen med universet, selvom læseren møder endnu en naturalisering af det lyriske subjekt i udtrykket »sjælens hellige have« (v. 48). Men denne have besidder ingen blomster, hvilket skal sættes i forhold til blomsterduftens rolle tidligere i digtet, hvor den var den formidlende instans mellem det himmelske og det jordiske. Det lyriske subjekts adskillelse fra det kosmiske kredsløb understreges i disse vers ved, at digtets centrale elementer (haven, blomsterne og forårsaftenen) bliver påkaldt på ny, men med en modsatrettet betydning i forhold til de første tre strofer. Forårsaftenerne (som jo er digtets overordnede tematiske repræsentation) bliver nu betragtet som et fantasifoster (»Hvor trist er det (...) at drømme om (...) fantastiske / forårsaftener» v. 47-52). ${ }^{15}$ Den metafysiske anskuelse i første del af digtet står med andre ord ikke længere til troende. »Primavera y sentimiento« udfolder altså både den metafysiske doktrin fra »Correspondances« og en skepticistisk position overfor denne.

Digtets sidste strofe kan anskues som en reprise af disse to betragtningsmåder, den panteistiske og den skepticistiske. Mens det var korrespondancesonettens paradigme der indledte digtet, bliver det imidlertid den skepticistiske position, som får det sidste ord. I sidste strofes første sætning (v. 7073) gentager det lyriske subjekt det ønske som indledte digtet: »Hvem der blot kunne opløses / i denne så vage farve / som oversvømmer rummet med / rene, duftende og hvide bølger«. Strofens og digtets sidste sætning udtrykker derimod ønsket om at indoptage den kosmiske helhed i subjektets indre og hæve den mod himlen »i min sjæls kalk« (v. 78). Anvendelsen af ordet 'kalk' indebærer en tvetydighed, som også findes på dansk. På den ene side gentages metaforen sjæl-blomst fra vers 11 via den 'døde' eller leksikaliserede metafor 'kalk' for 'blomsterbæger'. På den anden side kan anvendelsen af ordet 'kalk' også fortolkes i retning af et metapoetisk lag i digtet. Det lyriske subjekt hæver verden mod himlen i sin sjæls kalk på samme måde som den katolske præst hæver kalken under fejringen af eukaristien. Eukaristien er en repræsentation af Kristi offer for menneskehedens frelse, altså repræsentationen af en rituel ofring. Dette billede kan forklares, hvis man betragter første del af sætningen: »hvis verden altid var / en parfumeret aften / ville jeg hæve den mod himlen / i min sjæls kalk« (v. 74-75). Den parfumerede aften er netop, hvad der er blevet beskrevet i det digt, som læseren er ved at nå til vejs ende i, hvorved en subtil selvreferentialitet etableres. Det lyriske subjekts religiøse gestus kan i forlængelse af denne selvreferentialitet fortolkes som selve skrivningen af digtet, eftersom Jiménez tilhører en postromantisk litterær tradition, der betragter kunstudøvelsen som en religiøs handling. Det lyriske subjekt vil således identificeres som et digtersubjekt, metaforisk repræsenteret som en præst der udfører et ritual. 
Indenfor Correspondance-sonettens fortolkningsramme kunne metaforiseringen af digtersubjektet til en præst forstås som en fejring af universets selvbevidsthed. Digteren er talsmanden for de »rene, duftende og hvide bølger« (v. 73-74), der gennemstrømmer universet, på samme måde som præsten i kristendommen er den guddommelige nådes formidler. De to helsætninger, som sidste strofe består af, kan ydermere fortolkes som to komplementære fænomener i denne naturens kommen til selvbevidsthed gennem det digteriske jeg. På den ene side er det lyriske subjekt depersonaliseret i kraft af, at det ikke er dets 'selv', der taler, men naturens stemme, der lyder igennem det. På den anden side optræder subjektet som et nødvendigt konvergenspunkt, hvori verdens selvbevidsthed kan manifestere sig. Denne fortolkning ville brudløst følge den implicitte ontologi i »Correspondances«.

Selvom denne fortolkning således er indskrevet i digtet, er det som sagt ikke den, der får det sidste ord, idet den negeres af, at hele sidste strofe udsiges i condicional. Herved etableres en kontinuitet med fjerde strofes skeptiske attitude overfor den metafysiske forbindelse med naturtotaliteten. Verbalformen condicional indikerer, at subjektets opløsning og den komplementære emergens af universets stemme er et ønske, som ikke kan opfyldes. ${ }^{16} \mathrm{Nu}$ erfarer subjektet sig som en andethed i forhold til naturverden, hvorved dets aktivitet bliver til en artificiel kodning eller ciffrering af en meningsløs natur. $^{17}$

Poststrukturalistiske kritikere som Paul de Man, Michael Riffaterre og Jonathan Culler udviser konsensus med hensyn til antropomorfismens illusoriske karakter. Riffaterre finder, at prosopopeens funktion er at sætte læseren i en bestemt fortolkningsstemning ('a specific interpretive mood'), nemlig den hørende til den æstetiske reception. ${ }^{18}$ Culler og Riffaterre er enige i, at antropomorfismens funktion i lyrikken er artikulationen af et jeg-du forhold mellem subjektet og universet, ${ }^{19}$ men ifølge begge hviler dette forhold på en konvention som udelukkende er legitimeret af traditionen. ${ }^{20}$ Ifølge Riffaterre skal årsagen til at antropomorfismen betragtes som en central trope i lyrikken netop findes i dens artificialitet: „Efterligningen af noget i naturen umuligt [som det er tilfældet med prosopopeen - JHCJ] kan være et tegn på det fantastiske eller det overnaturlige eller det kan være en formal eller ludisk forestilling, en pseudohypotese eller, bedre, en hypoteses repræsentation, en figurativitetens figur. $\|^{21}$ Heraf følger, at poesi er et spil med hypoteser og fiktioner, hvilket vil sige, at referencen til den ekstralingvistiske virkelighed og til menneskelige erfaringer er irrelevant sammenlignet med lyrikkens tekstuelle egenart.

Ifølge Ricœur, som i denne henseende udfolder sin argumentation parallelt med Cassirers syn på den mytiske symbolske form som en primær re- 
spons på mødet med verden, blotlægger den poetiske diskurs en præobjektiv tilgang til virkeligheden. I Ricœurs fænomenologiske ramme artikulerer poesien en primær erfaring af verden, som svarer til hvad han kalder følelsesintentionaliteten. Følelsen er den intentionelle akt, som knytter subjektet til verden og til væren:

„Følelsens universelle funktion er at sammenknytte. Følelsen sammenknytter det som vores viden spalter, den knytter mig til tingene, til entiteterne, til væren. Mens enhver objektiverende bevægelse tenderer mod at sætte mig overfor en verden, forener følelsen den intentionalitet som kaster mig væk fra mig selv med den affekt (affection) ved hvilken jeg føler mig eksisterende. Tillige er følelsen altid på denne side af eller hinsides subjekt-objekt dualiteten. $\ll^{22}$

Denne intentionelle akt finder sin artikulation i den poetiske diskurs. Ganske parallelt med beskrivelsen af metaforens forbindelse med bevidsthedens billeddannende funktion, knytter Ricœur også følelsesintentionaliteten sammen med sproget. Gennem den sproglige artikulation af følelsesintentionaliteten udføres en epoché med hensyn til hverdagslivets emotionelle erfaringer. Følelsen etablerer et forhold til verden som ikke er struktureret ved subjektobjekt relationer, men ved en deltagelse i den:

»'Bølgernes glædesfyldte vuggen’ i Hölderlins digt er hverken en objektiv virkelighed i positivistisk forstand eller en stemning i emotivisk betydning. Sådan en kontrast anvendes i en forståelse hvor virkeligheden fra første færd er reduceret til videnskabelig objektivitet. Den poetiske følelses metaforiske udtryk angiver fraværet af skelnen mellem indre og ydre. Verdens 'poetiske teksturer' (...) og det indre livs 'poetiske skemaer' (...) spejler hinanden og erklærer det indre og det ydres reciprocitet« $(R M$, p. 246).

Ricœurs reciprocitet af indre og ydre udviser en påfaldende parallelitet med hvad der i denne artikel er blevet benævnt antropomorfismens reversibilitet. I forlængelse heraf kan man betragte antropomorfismen som en eksemplarisk trope med hensyn til den deltagelse i væren, som Ricœur et andet sted kalder »the experience of belonging« (RM, p. 313). Antropomorfismens status som paradigme for »the experience of belonging « ligger $i$, at artikulationen af denne erfaring ikke foregår på det tematisk-abstrakte plan, men på det figurative niveau. Figurativt sprog har en tensiv semantik, som frigør det sproglige udtryk fra en hverdagserfaring af verden. En ny metafor er et nyt per- 
spektiv på verden, en genbeskrivelse af verden. ${ }^{23}$ Antropomorfismens reversibilitet kan således forklares ved denne »experience of belonging«, da erfaringen af at føle et slægtskab med verden indebærer at kunne se et ydre naturelement som noget menneskeligt, og omvendt at kunne se en subjektiv tilstand som et naturfænomen.

Med Ricœurs fænomenologiske tilgang viser antropomorfismen sig som paradigmatisk for subjektets primære erfaring af væren i verden. Antropomorfismen er en stiftelse af mening, som ikke indebærer en narcissistisk selvspejling, men en kodning af verden som tillader os at bebo den ved at skabe et menneskeligt betydningsrum. En antropomorfisme er således ikke en illusorisk tilgang til verden, men en figur af vores beboelse af verden. Subjektet er rettet mod verden, og en måde at etablere et bånd til verden er ved at se noget som sig selv. At se som er, som nævnt ovenfor, grundlaget for den metaforiske operation (RM, p. 212-215) og en tilsynekomst af mening og erkendelse. I denne henseende er antropomorfismen en stiftelsestrope.

I denne artikel har begrebet om livsverden været taget forudsat idet poesien såvel som prosaen - med Merleau-Pontys formulering - taler et sprog for indviede, et sprog som deles af såvel forfatter som læser: »Romanforfatteren taler med sin læser, som ethvert menneske med ethvert andet, et sprog for indviede: indviede i verden, i det univers af muligheder som en menneskekrop, et menneskeliv råder over. $\|^{24}$ I Merleau-Pontys formulering om sproget for de indviede ligger den nødvendige krydsrelation mellem sprog og sanseverden, som både han og Ricœur har fremhævet i deres filosofi. I en passage der har strukturalismen som sigte, men som i høj grad foregriber den poststrukturalistiske fejde, afviger Merleau-Ponty fra det synspunkt, at subjektet er fanget $i$ et sprog, hvor hvert tegn kun henviser til andre tegn i det uendelige. I stedet lever mennesket i en udveksling mellem sprog og verden:

»Tegnene henviser for os ikke blot til andre tegn og således i det uendelige, sproget er ikke som et fængsel, vi er fanget i, eller en fører, der må følges blindt, for i skæringspunktet mellem alle disse sproglige gestus viser det sig med ét hvad de vil sige; hertil skaffer de os en så fuldstændig adgang, at vi ikke længere synes at have brug for dem for at kunne henvise til det. $\aleph^{25}$

Sprogets rettethed mod andre og mod verden indebærer ydermere, at sprogsystemet ikke er et én gang for alle lukket system, men derimod et dynamisk betydningskorpus, som konstant lader nye eller ikke-artikulerede meninger udkrystallisere. 
Den ciffrering af selvet og af verden, som blev fremanalyseret $\mathrm{i}$ »Primavera y sentimiento« er nødvendigvis en tofoldig procedure. På den ene side er den betinget af denne akts lingvistiske beskaffenhed, men på den anden side relaterer den også til en kropslig erfaring af selv og verden. Det kiastiske forhold mellem verden og sprog er således tilgrundliggende for sprogets mulighed for at nå udover sig selv, idet en ciffrering altså er en måde at »erobre « ${ }^{26}$ indsigter om verden, som fremkommer i samme øjeblik som de formuleres. Således er det igennem sproget muligt at tilegne sig den mening, som så at sige er iboende i perceptionen. Når først det sproglige udtryk har emergeret fra perceptionens tavse verden har det åbnet et aspekt af verden for bevidstheden. Ifølge Merleau-Ponty og Ricœur artikulerer sproget en mening som ikke blot er et rent kulturelt konstrukt, men som er latent tilstede i verden før sproget tager det i besiddelse. På sin vis er denne ide parallel med romantisk naturfilosofi og med den implicitte ontologi i »Correspondances« : Naturen besidder en iboende mening og sproget artikulerer denne mening. Overgangen fra natur til sprog er brudløs, og denne udkrystallisering af mening er uendelig, for på samme måde som perceptionen af en given ting aldrig er absolut fordi tingen aldrig som helhed vil være tilstede for sanserne, er sprogets »blik« også altid rettet fra ét givent perspektiv. Antallet af mulige perspektiver, hvorfra man kan tilegne sig nye betydninger er uendeligt, i og med at ethvert fænomens variationer er uudtømmelige.

En for yderliggående ontologisk fortolkning af den netop fremlagte sproglige tilegnelse af verden bør imidlertid undgås, da fristelsen for at indtræde i en vitalistisk ontologi ligger lige for. Snarere end forbundet med en filosofisk vitalisme skal meningens dynamiske fremtræden fra sanseverden ses forbundet med intentionalitetsbegrebet. Eftersom det figurative udtryk er relateret til virkelighedens perspektiviske tilegnelse, er det tilhørerens eller læserens bevidsthed, der er det »sted«, hvor »the blossoming of appearing« ( $R M, p$. 309) fremtræder, d.v.s. hvor det poetiske sprog afslører potentialer af erfaring og forståelse. Men dette betyder også, at antropomorfismen er, til trods for dens indlysende biologiske givethed, betinget af en hermeneutisk kompetence hos modtageren. Sprogsystemet er det medium gennem hvilket subjektet artikulerer erfaringen af at være i verden i en udveksling mellem de allerede krystalliserede betydninger og ny meningers opdukken. Litteraturfortolkningen fordrer således en konvergens af fænomenologi og hermeneutik, eftersom forud for ethvert subjekt går både en verden og et sprogligt og kulturelt korpus af betydninger. 


\section{Appendiks}

\section{Primavera y sentimiento}

1 Estos crepúsculos tibios

2 son tan azules, que el alma

3 quiere perderse en las brisas

4 y embriagarse con la vaga

5 tinta inefable que el cielo

6 por los espacios derrama,

7 fundiéndola en las esencias

8 que todas las flores alzan

9 para perfumar las frentes

10 de las estrellas tempranas.

11 Los pétalos melancólicos

12 de la rosa de mi alma,

13 tiemblan, y su dulce aroma

14. (recuerdos, amor, nostalgia),

15 se eleva al azul tranquilo,

16 a desleirse en su mágica

17 suavidad, cual se deslíe

18 en un sonreír la lágrima

19 del que sufriendo acaricia

20 una remota esperanza.

21 Está desierto el jardín;

22 las avenidas se alargan

23 entre la incierta penumbra

24 de la arboleda lejana.

25 Ha consumado el crepúsculo

26 su holocausto de escarlata

27 y de las fuentes del cielo

28 (fuentes de fresca fragancia),

29 las brisas de los países

30 del sueño, a la tierra bajan

31 un olor de flores nuevas

32 y un frescor de tenues ráfagas...

33 Los árboles no se mueven,

34 y es tan medrosa su calma,

35 que así parecen mas vivos

36 que cuando agitan las ramas;

37 y en la onda transparente

38 del cielo verdoso, vagan

39 misticismos de suspiros

40 y perfumes de plegarias.

41 iQué triste es amarlo todo

42 sin saber lo que se ama!

43 Parece que las estrellas

44 compadecidas me hablan, 
45 pero como están tan lejos,

46 no comprendo sus palabras.

47 iQué triste es tener sin flores

48 el santo jardín del alma,

49 soñar con almas floridas,

50 soñar con sonrisas plácidas,

51 con ojos dulces, con tardes

52 de primaveras fantásticas!...

53 iQué triste es llorar, sin ojos

54 que contesten nuestras lágrimas!

55 Ha entrado la noche; el aire

56 trae un perfume de acacias

57 y de rosas; el jardín

58 duerme sus flores... Mañana,

59 cuando la luna se esconda

60 y la serena alborada

61 dé al mundo el beso tranquilo

62 de sus lirios y sus auras,

63 se inundarán de alegría

64 estas sendas solitarias;

65 vendrán los novios por rosas

66 para sus enamoradas;

67 y los niños y los pájaros

68 jugarán dichosos... ¡Almas

69 de oro que no ven la vida

70 tras la nube de las lágrimas!

71 ¡Quién pudiera desleirse

72 en esa tinta tan vaga

73 que inunda el espacio de ondas

74 puras, fragantes y pálidas!

75 ¡Ah, si el mundo fuera siempre

76 una tarde perfumada,

77 yo lo elevaría al cielo

78 en el cáliz de mi alma!

Juan Ramón Jiménez: Primeros libros de poesía, Madrid, 1959, pp. 89-91.

\section{Noter}

1. Paul de Man: The Rhetoric of Romanticism, New York 1984, p. 241 (herefter forkortet $R R)$.

2. Paul Ricœur: The Rule of Metaphor. Multi-disciplinary studies of the creation of meaning in language, London, 1978, p.213 (herefter forkortet RM). Der henvises til den engelske udgave af La métaphore vive eftersom Ricœur indførte ændringer i denne oversættelse i forhold til den franske førsteudgave. 
3. Således vil Eluards »La terre est bleue comme une orange« ikke være at regne for en metaforisk operation, eftersom der ingen lighedsrelation er at finde mellem planeten jordens blå farve og appelsinens orange farve (litteraturhistorisk bør dette citat forstås ud fra det surrealistiske projekts oprør mod rationalitetens hegemoni i vestlig tænkning).

4. Paul Ricœur: »The Metaphorical process as Cognition, Imagination, and Feeling«, in: Sacks, Sheldon: On Metaphor, Chicago 1979, p. 142. Dansk oversættelse: »Den metaforiske proces«, in Jørgen Holmgaard \& Per Krogh Hansen (red.): Billedsprog, Kbh. 1997.

5. Cassirers neokantianske position observeres derved, at de symbolske former ikke er billeder eller repræsentationer af virkeligheden an sich, men er vores virkelighedserfarings former. At erkende vil ifølge Cassirer sige at danne en syntese af de perceptuelle signaler gennem forståelseskategorier. Der findes ingen uformidlet eller neutral erfaring af virkeligheden, perceptionen er altid formet til at blive forstået på en given måde: „Også det tilsyneladende 'givne' viser sig ved skarpere analyse allerede at have gået igennem bestemte handlinger (Akte), det være sig den sproglige, den mytiske eller den logisk-teoretiske 'apperception'. Noget 'er' kun det som det bliver gjort til i disse handlinger.« Ernst Cassirer: Philosophie der Symbolischen Formen II, Berlin 1925, p.120 (herefter forkortet PSF II; de øvrige to bind, udgivet i 1923 og 1954 forkortes henholdsvis PSF I og PSF III).

6. „Bestemte begreber - tal- tids- og rumbegrebet - som fremstiller syntesens urformer er uomgængelige for så vidt en 'flerhed' skal samles til en 'enhed' eller noget mangfoldigt overhovedet skal opdeles og ordnes efter bestemte gestalter. Men denne inddeling udføres ikke på ensartet vis i alle domæner. Derimod afhænger inddelingsmåden afgørende af det særlige strukturprincip som er virksomt og hersker i hvert særdomæne« PSF III, p.17.

7. »Det som nedsænkningen i den rene perception af livet viser os er i alle fald dette ene: at perceptionen af livet aldrig går op i den blotte perception af tingene. Erfaringen af 'du'et' kan gennem nok så komplekse begrebslige formidlinger aldrig opløses i eller reduceres til erfaringen af det blotte 'det'. Også fra et rent genetisk synspunkt hersker ingen tvivl om hvilken af de to perceptionsformer der skal tilskrives prioritet. Jo længere vi forfølger perceptionen tilbage desto mere vinder 'du'ets' form fortrin fremfor 'det's' form; så meget tydeligere har perceptionens rene udtrykskarakter overvægt fremfor sag- og tingskarakteren«(PSF III, pp. 7374).

8. Her i Sigurd Swanes oversættelse Charles Baudelaire: Syndens blomster, Kbh. 1979.

9. Michael Riffaterre: »Prosopopeia«, YFS 69 (1985), p. 112.

10. Ibid.

11. Juan Ramón Jiménez (1881-1958) er ubestridt en af de væsentligste skikkelser i den spansksprogede poesi i det 20. århundrede. Hans værk udvikledes fra en æsteticistisk fin de siècle lyrik til en nøgtern poesía pura.

12. Benyttelsen af præpositionen "para» (her oversat med »for at«) angiver at det grammatiske subjekt, i dette tilfælde blomsterne, har en hensigt med den pågældende handling.

13. I originalen: Perderse, embriagarse, tiemblan, elevarse, desleirse, alargarse, moverse, vagar.

14. Især ved bestemte se-konstruktioner, der på dansk svarer til man-konstruktioner. For Jiménez' vedkommende er den nævnte stilistiske fremgangsmåde blevet be- 
mærket af Richard Cardwell: Juan R. Jiménez: the Modernist Apprenticeship, 1895-1900, Berlin, 1977, p. 154-159.

15. Udover anvendelsen af verbet »at drømme«, kan man anføre at benyttelsen af adjektivet »fantástico«ikke skal forstås i betydningen »strålende« eller »storslået", men i dets egentlige forstand, som betegnende en illusorisk eksistens. Dette fremgår af udgaverne fra 1869, $1899 \mathrm{og}$ 1914 af Diccionario de la Real Academia Española de la Lengua, hvori definitionen af adjektivet 'fantástico' lyder: 'adj. Quimérico, fingido, que no tiene realidad y consiste sólo en la imaginación. // Presuntuoso y entonado.' Først i 1992 udgaven af DRAE er følgende definition tilføjet: 'fig. y fam. Magnífico, excelente.'

16. Dette angives af udtrykket som indleder strofen, »iQuién pudiera!« (»Hvem der kunne«), der utvetydigt udtrykker umuligheden af det ønskede.

17. Der er således en iøjnefaldende lighed mellem denne skepticistiske position i digtet og en litteraturkritisk tilgang, hvor sproget har det totale primat i forhold til erfaringen af verden. Denne parallelitet angiver, at adskillelsen mellem forskningsobjektet og den analytiske tilgang til det ikke er ganske entydig i de humanistiske videnskaber. Det kunne således virke som om både forskningstilgangen og forskningsobjekterne har et bredere ånds- eller idehistorisk paradigme til fælles. I dette tilfælde finder man en påfaldende parallelitet mellem på den ene side en tekstuel litteraturopfattelse og den skepticistiske attitude, der kommer til syne i sidste del af digtet, og på den anden side en fænomenologisk tilgang og korrespondancetænkningen i første del af digtet. Disse positioner er i høj grad tilstede i fin de siècle-litteraturen og dermed i Jiménez' hermeneutiske horisont. Som eksempler kunne Baudelaire stå på den fænomenologiske side, mens Mallarmé kunne stå som repræsentant for en tekstuel poetisk praksis.

18. Michael Riffaterre: »Prosopopeia«, YFS 69 (1985), p. 108.

19. Michael Riffaterre: »Prosopopeia«, YFS 69 (1985), p.111. Jonathan Culler: The Pursuit of Signs. semiotics, Literature, Deconstruction, New York 1981,pp.140143

20. Riffaterre, loc.cit., p.116. Culler, op.cit., p. 143.

21. Riffaterre, loc.cit., p.110.

22. Paul Ricœur: Finitude et culpabilité vol. I. L'homme faillible, Paris, 1963, p.147.

23. Ricœur betragter forståelsen af en metafor som en proces der indeholder tre momenter: „Indbildningskraften skematiserer ikke blot den prædikative assimilering mellem tingene ved dens syntetiske indsigt i ligheder, og den billedliggør heller ikke blot dens mening takket være udfoldelsen af billeder fremkaldt og kontrolleret af den kognitive proces. Den bidrager snarere konkret til den almindelige references epoché og til projektionen af nye muligheder for at genbeskrive verden.« Paul Ricœur: »The Metaphorical process as Cognition, Imagination, and Feeling«, in: Sacks, Sheldon: On Metaphor, Chicago 1979, p. 152 (forfatterens kursiv).

24. Maurice Merleau-Ponty: Tegn: udvalgte essays (ov. P.A. Brandt), Kbh., 1969, p.126.

25. Op.cit., pp. 132-133.

26. "langage conquerant", Maurice Merleau-Ponty: Signes, Paris 1960, p. 97. 